\title{
The source of progesterone in rabbit blastocysts
}

\author{
S. Fujimoto* and K. Sundaram \\ The Population Council, Rockefeller University, New York, New York 10021, U.S.A.
}

\begin{abstract}
Summary. High levels of progesterone were found in the blastocysts, uterine fluid and sera of normal pregnant rabbits on Days 6 and 7 of pregnancy. Very little progesterone $(<2 \%$ of control) was present in bilaterally ovariectomized rabbits in which pregnancy was maintained by the administration of medroxyprogesterone acetate. The results demonstrate that the rabbit blastocyst is provided with large amounts of progesterone derived from the maternal ovaries.
\end{abstract}

\section{Introduction}

Dickmann \& Spilman (1975) have reported the detection of prostaglandins in rabbit blastocysts and suggested that these substances may be involved in the regulation of steroidogenesis by the blastocyst. The presence of steroidogenic enzymes in 6-day post coitum rabbit blastocysts has been demonstrated by histochemical methods (Dickmann, Dey \& Gupta, 1975). Huff \& Eik-Nes (1966) have shown that rabbit blastocysts can synthesize pregnenolone from acetate in vitro, but other investigators have found significant amounts of progesterone and other steroids in the rabbit blastocysts and uterine fluid and have suggested that the steroids are derived from maternal sources rather than representing de novo synthesis by the blastocyst (Seamark \& Lutwak-Mann, 1972; Borland, Erickson \& Ducibella, 1977).

In the present study we have measured the progesterone levels in the blastocysts of 6- and 7-day pregnant ovariectomized rabbits in which pregnancy was maintained by the administration of medroxyprogesterone acetate (MPA), a potent progestin. MPA has previously been utilized to support pregnancy in the ovariectomized rabbit (Thau \& Lanman, 1974).

\section{Materials and Methods}

Sexually mature virgin New Zealand White rabbits were induced to ovulate by i.m. injection of 100 i.u. PMSG followed 4 days later by i.v. administration of 100 i.u. hCG and mated with fertile males immediately before the hCG injection. In 14 rabbits bilateral ovariectomy was performed under pentobarbital anaesthesia $44 \mathrm{~h}$ after mating, 3 rabbits were sham operated and 11 served as intact controls. Medroxyprogesterone acetate (Upjohn Co., Kalamazoo, Michigan) treatment (5 mg/day, i.m.) was begun immediately after ovariectomy. The rabbits were killed at $149 \mathrm{~h}$ (Day 6) and $175 \mathrm{~h}$ (Day 7) post coitum. The uterine horns from the 6-day-pregnant rabbits were flushed with $5 \mathrm{ml} \mathrm{0.154}$ $\mathrm{M}-\mathrm{NaCl}$ (saline), and the blastocysts recovered were washed 3 times with saline. The blastocysts were then ruptured, centrifuged and the supernatant obtained. The blastocoele fluid from the Day 7 blastocysts was aspirated directly through the uterine wall with a syringe and needle. Then the uterine horns were flushed with $5 \mathrm{ml}$ saline. Before being killed serum samples were obtained from all rabbits. All samples were kept frozen at $-20^{\circ} \mathrm{C}$ until steroid analysis.

Progesterone was determined by radioimmunoassay according to the method of Thorneycroft \& Stone (1972). An antiserum to progesterone-11-BSA with a cross reactivity of $0.7 \%$ for $20 \alpha$-dihydroprogesterone, $0.9 \%$ for $17 \alpha$-hydroxyprogesterone and $0.2 \%$ for pregnenolone was used for the assay. The antiserum did not cross-react with MPA. The sensitivity was $25 \mathrm{pg} / \mathrm{ml}$ and the assay variation was $18 \%$.

\footnotetext{
* Present address: Department of Obstetrics and Gynecology, Hokkaido University School of Medicine, Sapporo,
} Hokkaido, Japan. 


\section{Results}

As shown in Table 1, high levels of progesterone were found in the blastocysts, uterine fluid and maternal serum of rabbits on Days 6 and 7 of pregnancy. In the intact control rabbits the concentration of progesterone in the maternal serum was 2- to 3-fold higher than that in the blastocyst fluid. In spite of the fact that the uterine lumen was flushed with $5 \mathrm{ml}$ saline, leading to a considerable dilution of the contents that were expelled, the concentration of progesterone in this fluid was quite high.

Table 1. Progesterone levels (mean \pm s.e.m.) in the maternal serum, blastocysts and uterine fluid of intact and ovariectomized pregnant rabbits

\begin{tabular}{|c|c|c|c|c|c|}
\hline \multirow[b]{2}{*}{ Group } & \multirow[b]{2}{*}{$\begin{array}{c}\text { No. of } \\
\text { animals }\end{array}$} & \multirow[b]{2}{*}{$\begin{array}{c}\text { Day of } \\
\text { pregnancy }\end{array}$} & \multicolumn{3}{|c|}{ Progesterone (ng/ml) } \\
\hline & & & $\begin{array}{l}\text { Maternal } \\
\text { serum }\end{array}$ & $\begin{array}{c}\text { Blastocyst } \\
\text { fluid }\end{array}$ & $\begin{array}{l}\text { Uterine } \\
\text { fluid* }\end{array}$ \\
\hline Intact control & 5 & 6 & $21 \cdot 2 \pm 5 \cdot 28$ & $6 \cdot 6 \pm 1 \cdot 81$ & $16.7 \pm 3 \cdot 83$ \\
\hline Intact sham-operated & 3 & 6 & $17.0 \pm 2.75$ & $6 \cdot 3 \pm 1 \cdot 62$ & $12 \cdot 5 \pm 1 \cdot 23$ \\
\hline Ovariectomized $\dagger$ & 2 & 6 & $0 \cdot 4,0 \cdot 18$ & - & $0.05 \pm 0.01$ \\
\hline Ovariectomy + MPA (5 mg/day) & 8 & 6 & $0.25 \pm 0.15$ & $0.1 \pm 0.03$ & $0.03 \pm 0.01$ \\
\hline Intact control & 6 & 7 & $22 \cdot 7 \pm 5.44$ & $13 \cdot 1 \pm 1 \cdot 90$ & $7 \cdot 2 \pm 1 \cdot 22$ \\
\hline Ovariectomy + MPA (5 mg/day) & 4 & 7 & $0.16 \pm 0.04$ & $0.2 \pm 0.07$ & $0.06 \pm 0.01$ \\
\hline
\end{tabular}

* Each uterine horn was flushed with $5 \mathrm{ml}$ saline.

$\dagger$ Bilateral ovariectomy was performed $44 \mathrm{~h}$ post coitum.

Blastocysts could not be recovered from any of the ovariectomized animals that did not receive supplemental progestagen therapy. Ovariectomized pregnant rabbits that received MPA daily yielded blastocysts of normal size on Days 6 and 7 of pregnancy. In these animals the blastocysts as well as the uterine fluid and maternal serum contained very little progesterone (Table 1).

\section{Discussion}

In the present study, relatively large amounts of progesterone were found in the blastocysts of 6-and 7-day-pregnant rabbits, but very little was found in the blastocysts of ovariectomized rabbits in which pregnancy was maintained by the administration of a synthetic progestagen, indicating that almost all the progesterone found in the normal blastocysts is derived from the maternal ovaries. The small amounts of progesterone detected in the blastocysts of ovariectomized animals may represent de novo synthesis of the steroid by the blastocyst or may be derived from the maternal adrenal glands, which have been shown to secrete significant amounts of progesterone in ovariectomized rats (Fajer, Holzbauer \& Newport, 1971) and monkeys (Resko, 1971).

The results presented in Table 1 also suggest that the concentration of progesterone in the intrauterine fluid is much higher than that in the maternal serum. Based on their own results and other evidence, Borland et al. (1977) have suggested that special features exist in the rabbit uterus which permit the accumulation of steroids in the uterus at concentrations higher than that found in the maternal serum, and, further, that the blastocysts derive their progesterone from the uterine fluid. The results of the present experiment provide strong evidence that the rabbit blastocyst is indeed inundated with progesterone from the maternal ovaries. Even if the intrauterine environment and the blastocysts of rabbits are well supplied with steroids from the mother, the physiological significance of the detection of steroidogenic enzymes (Dickmann et al., 1975) and the demonstration of de novo synthesis of some steroids by the blastocysts (Huff \& Eik-Nes, 1966) remains to be elucidated. 


\section{References}

Borland, R.M., Erickson, G.F. \& Ducibella, T. (1977) Accumulation of steroids in rabbit preimplantation blastocysts. J. Reprod. Fert. 49, 219-224.

Dickmann, Z. \& Spilman, C.H. (1975) Prostaglandins in rabbit blastocysts. Science, $N . Y$. 190, 997-998.

Dickmann, Z., DeY, S.K. \& GUPTA, J.S. (1975) Steroidogenesis in rabbit preimplantation embryos. Proc. natn. Acad. Sci. U.S.A. 72, 298-300.

Fajer, A.B., Holzbauer, M. \& Newport, H.M. (1971) The contribution of the adrenal gland to the total amount of progesterone produced in the female rat. J. Physiol., Lond. 214, 115-126.

HuFr, R.L. \& EIK-Nes, K.B. (1966) Metabolism in vitro of acetate and certain steroids by six-day-old rabbit blastocysts. J. Reprod. Fert. 11, 57-63.

Resko, J.A. (1971) Sex steroids in adrenal effluent of the ovariectomized rhesus monkey. J. clin. Endocr. Metab. 33, 940-948.

Seamark, R.F. \& Lutwak-Mann, C. (1972) Progestins in rabbit blastocysts. $J$. Reprod. Fert. 29, 147-148.

Thau, R. \& Lanman, J.T. (1974) Evaluation of progesterone synthesis in rabbit placentas. Endocrinology 94, 925-926.

ThORNEYCROFT, I.H. \& Stone, S.C. (1972) Radioimmunoassay of serum progesterone in women receiving oral contraceptive steroids. Contraception 5, 129-146.

Received 30 May 1977 